\title{
Benefits and Challenges of Online Teaching During the COVID-19 Pandemic at Rundu Campus of the University of Namibia
}

Emilia N Mbongo, $(\mathrm{PhD})$

Anna N Hako, $(\mathrm{PhD})$

School of Education, University of Namibia

Takaedza Munangatire, $(\mathrm{PhD})$

School of Nursing, University of Namibia

\section{Abstract:}

This paper presents the benefits and challenges of online teaching during the COVID-19 pandemic experienced by educators at the Rundu Campus of the University of Namibia. Researchers used a structured interview guide to collect data from 14 conveniently selected lecturers from a population of 65. Findings of the study indicate that the benefits of using online teaching and learning include flexibility, ability to teach large classes; increased interaction and engagement between lecturers and students; and increased learning opportunities for lecturers. The study further found that some of the significant challenges lecturers experienced with online teaching and learning include lack of information and technology skills, internet connectivity and availability; poor student attendance; and loneliness. The study provided crucial information on lecturers' progress within the framework of online teaching and learning mode. The paper recommends that lecturers receive formal training on online teaching and learning tools to minimise the limitations. The study also suggests increased psychosocial support for lecturers to curb feelings of isolation and loneness during this time. Covid-19

Key Words: online teaching, online learning, challenges, benefits,

\section{Background and context}

The beginning of 2020 saw a rapid increase in the cases of the novel coronavirus (COVID-19) (World Health Organization (WHO), 2020). By March 2020, the number of COVID-19 cases outside China (where it was 
thought to have originated) had increased 13-fold across many countries (WHO, 2020). By March 2020, WHO has declared the COVID-19 virus a pandemic (WHO, 2020). It was also around the same time Namibia reported the first case of COVID-19. The increasing instances of COVID-19 necessitated that people change their usual ways of living to minimise the spread of the virus. Namibia imposed the State of Emergency in March 2020. Among the conditions of the State of Emergency was that all government employees and those in the State-Owned Enterprises and private sectors were to operate from home (MoEAC, 2020). Schools and all non-emergency operations were to close. The institutions of higher learning were not spared and had to come up with innovative ways to carry out their core functions- that of teaching and learning. The University of Namibia declared that teaching and learning should shift from a primarily face-to-face approach to online teaching and learning.

In a small town called Rundu in North-Eastern Namibia lies the University of Namibia's Rundu Campus. The UNAM: Rundu Campus was a government-owned teacher training college before the Faculty of Education of the University of Namibia in 2010 absorbed it (Moses, 2010). Merging the colleges with the University was done to improve the educational standards. Although the Rundu campus is open to everyone in Namibia, it mainly caters to students residing in the Kavango East and West regions. The two Kavango regions rank among the poorest regions in Namibia Statistics Agency (2012). It is also worth noting that most students come from rural areas where poverty is even higher. Furthermore, the provision of essential services such as water and electricity is still poor.

It was thus a challenge when teaching and learning shifted to online due to the COVID-19 pandemic. Students had to attend live virtual classes, write tests, and write and submit assignments online with online teaching and learning. On the other hand, lecturers had to teach live virtual classes, set and upload tests and assignments, grade them and, record lessons. Both lecturers and learners used Web communication platforms and teaching tools such as Zoom, Panopto, Moodle, BigBlue Button, Google Drive, Microsoft Teams, WhatsApp, etc. Teaching online would require lecturers to be technologically savvy to make full use of these services.

Information literacy, media literacy, and technology literacy are among the top skills needed in the $21^{\text {st }}$ century. Migrating from mainly faceto-face to online teaching and learning at the University of Namibia required lecturers and students to possess these critical $21^{\text {st }}$-century skills. The COVID19 pandemic has caused many higher institutions of learning to change their usual way of teaching. When the COVID-19 pandemic hit the world, the University of Namibia had to shift education from a mainly face-to-face approach to strictly online teaching and learning. It is palpable that such a change would come with challenges, both from educators' and students' sides. 
It may also come with positive experiences for both lecturers and students. It was thus worth finding out the lecturers' experiences of online teaching. The study aimed to explore the benefits and challenges of online teaching and learning as experienced by lecturers during the COVID-19 pandemic at the Rundu Campus of the University of Namibia.

\section{Objectives of the study}

The objectives of the study are:

i. To investigate the challenges of online teaching as experienced by lecturers' during the COVID-19 at the University of Namibia

ii. To describe the benefits of online teaching as experienced by lecturers' during the COVID-19 at the University of Namibia

\section{Literature review}

\section{Benefits of online teaching and learning}

In response to the covid-19 pandemic, the delivery of education across the globe has changed drastically. Online teaching and learning have taken centre stage in many schools and institutions of higher learning. According to Mathew and Iloanya (2016), using technology for teaching and learning has enhanced education and positively impacted the education process. Teaching online has existed long before the Covid-19 pandemic, and several researchers found it to be beneficial. Stone and Perumean-Chaney (2011) noted that one of the benefits of online teaching enables instructors to devise varied strategies for submitting course work and provides additional arenas for the instructor to clarify misunderstandings in a forum in which all students can participate. Another notable advantage of online teaching and learning, as Mukhtar, Javed, Arooh and Sethi (2020) found in their study on online learning, was that it had encouraged student-centred learning. It is a fact that learning is much more successful when students take ownership and are involved in the process.

\section{Challenges of online teaching}

In a traditional lecture room, the role of the educator was to lecturer students who sat in neat rows of desks as they listened attentively and took notes. As times changed, this role evolved to that of a facilitator as students took a more active part in the learning process with discussions and presentations. With the sudden shift from face-to-face teaching to online teaching, many lecturers and students were left perplexed.

Among the many challenges lecturers faced with online teaching is computer technology skills. Few lecturers were formally trained on information and computer skills, let alone on teaching through online platforms (Mutisya \& Makokha, 2016). Lack of information and computer skills is a massive challenge that has the potential to impede online teaching. In Addition to technology challenges, online education requires developing 
and using more inclusive approaches that capture different learning styles (Sithole, Mupinga, Kibirige, Manyanga \& Bucklein, 2019). Online teaching requires that lecturers utilise a variety of skills to keep students abreast and interested.

Given that online teaching and learning is a relatively new concept to both experienced and novice educators, professional development is necessary, including effective course design, instruction, implementation, and evaluation. The situation is even worse in developing countries where access to the internet is limited compared to developed countries. A study conducted in a Botswana university found that unreliable internet access was a significant challenge to online teaching and learning (Mathew \& Iloanya, 2016). Similarly, Dube (2020) discusses that the success of online teaching and learning was hampered by the unavailability of internet connectivity in some rural areas. Studies have also found that teaching online took much more time than face-to-face teaching (Assareh \& Bidokht, 2010; Protsiv \& Atkins, 2016).

\section{Methodology}

The study was conducted at the Rundu Campus of the University of Namibia, which comprises 65 lecturers. Using the convenience sampling procedure, 14 lecturers took part in the study. The study followed a qualitative approach to research which allowed for in-depth analysis and understanding of the lecturers' experiences about online teaching during the COVID-19 pandemic.

Data were collected through one-on-one structured interviews with the lecturers, ensuring that Covid-19 regulations were observed. With structured interviews, the researchers had specified questions to elicit information about the benefits and challenges of online teaching as experienced by the participants (Gay, Mills \& Airasian, 2012; Johnson \& Christenson, 2012). The interview questions were in line with the study's objectives to ensure that the aims of the study were achieved. Participants were also asked whether they had formal training in computer skills or not. Table 1 gives a summary of the characteristics of the participants.

Table 1: Characteristics of the participants

\begin{tabular}{|l|l|l|l|l|}
\hline Pseudo name & Sex & Age & $\begin{array}{l}\text { Lecturing } \\
\text { Experience } \\
\text { (years) }\end{array}$ & $\begin{array}{l}\text { Formal } \\
\text { Training in } \\
\text { ICT }\end{array}$ \\
\hline Jonn & Male & 41 & 5 & Yes, ICDL \\
\hline Angelina & Female & 55 & 5 & no \\
\hline Alice & Female & 65 & 20 & no \\
\hline Mat & Male & 39 & 8 & no \\
\hline Sara & Female & 50 & 17 & yes \\
\hline Aimee & Female & 40 & 3 & Yes \\
\hline
\end{tabular}




\begin{tabular}{|l|l|l|c|l|}
\hline Ramos & Male & 41 & 11 & Yes \\
\hline Toini & Female & 46 & 16 & No \\
\hline Namene & Female & 42 & 7 & No \\
\hline Loide & Female & 35 & 3 & No \\
\hline Mat & Male & 64 & 24 & No \\
\hline Faust & Female & 41 & 5 & No \\
\hline Teres & Female & 43 & 1 & No \\
\hline Saima & Female & 53 & 17 & No \\
\hline
\end{tabular}

For this study, the participants were informed about the benefits of their participation and the benefits the study would contribute to the University. Furthermore, participants were informed of their right to participate in the research or to discontinue at any time. Participants were also informed that data gathered would only be used for this study. The use of pseudo names ensured the confidentiality and anonymity of the participants.

In analysing data, the researchers firstly transcribed and organised the data. Transcription means transforming qualitative data into text (Johnson \& Christenson, 2012). The next step involved segmenting, coding, and developing category systems. Data reporting took the form of descriptive words, verbatim quotations, and a table.

\section{Results and Discussion}

This section presents the results, analysis, and discussion. Presentation, analysis, and discussion of the results follow the order of the research objectives.

\section{Benefits of online teaching}

Online teaching came with advantages, as discussed below. Participants indicated that the ability to teach from the comfort of their offices or homes was one of the advantages that came with online teaching. This and other benefits are discussed below:

Flexibility: Participants narrated how online teaching enabled them to teach from their offices' comfort or even their houses. As Angelina narrated:

Online teaching was very convenient, as I did not have to drive to work on a daily. I conducted most of my teaching, compiling, and grading assessment activities from home. It allowed me to carry out my household chores, spend time with family while working.

Deciding when to have their classes also came out as a benefit of online teaching, as lecturers had to choose when to have lessons, as there was no strict timetable or teaching schedule to follow. The findings of this study support existing evidence that most lecturers considered time flexibility an advantage of online teaching (Zalat, Hamed \& Bolbol, 2021). The ability to record lessons was also an advantage of online education that many participants reported. The option of recording lessons allowed students to access them whenever it was convenient for them. Because of the poor economic 
background of most students at the Rundu Campus, many students could not access live lessons due to internet unavailability and depended on the recorded lectures.

Handling many students: Some courses/modules, especially core modules, have many students. Online teaching made it easy as lecturers could teach them all at the same time, as narrated by Aimee

I usually have close to 400 students in one of my modules. Often, they get split into two groups for lecturing, which instantly doubles the workload. With online teaching, it was easier as I could teach them all at once. With online, administering and grading activities was also more manageable. Given a chance, I would continue with online teaching, especially for large groups.

Participants reported that online teaching helped them to handle large numbers of students at once. Many students could easily be handled online with online teaching and learning, unlike in the face-to-face scenario. However, this contradicts other findings, which showed that faculty considered e-learning time-consuming and made student monitoring difficult, resulting in students losing interest (Bhardwaj, Nagandla, Swe and Abas, 2015). Furthermore, participants are of the view that online teaching made grading of assessment activities online easier. These findings are in line with the study results by Horner, Classick, Warren and Durbin (2018), which reported that teachers found that the automated marking of assessment activities reduced the time and effort needed to grade assessments.

Increased interaction between lecturers and students: The many online teaching and communication platforms such as discussion forums on BigBlueButton, Panopto, Zoom, and WhatsApp increased engagement between students and lecturers compared to the traditional way of teaching. Lecturers reported that many students used the discussion forums and WhatsApp, which allowed them to participate in discussions instead of faceto-face learning. Even shy students who would typically not say anything in class were taking part in discussions. As it often happens, many students seemed to lose their inhibitions behind the keyboards and participated in discussions freely. According to Mathew and Iloanya (2016), interaction can promote students motivation and enhance the learning process. Online platforms also made it easy to share learning material such as notes and reference materials. On the other hand, lecturers indicated that online teaching made informal assessment difficult, if not impossible. Oncu and Cakir (2011) also found similar findings in their study, which suggested that the lack of face-to-face interaction made informal assessment difficult for lecturers.

Learning opportunity: Online teaching brought a learning opportunity for many lecturers. They indicated how they had to learn new things about technology, which they did not know before. Alice made the following comments: 
Although it felt like we were thrown in the deep end, I learned a lot. Now I can comfortably use Moodle to teach, set, upload, and grade assessment activities, send mail to all students at once, whereas before, I only used Moodle to grade assignments.

As Alice said above, lecturers were opened up to a myriad of opportunities that they can use in their online teaching instead of traditional teaching methods. John indicated that learning how to share documents online or send links to students to read improved his teaching. He noted that many students found it difficult before to go to libraries and read. With books, documents, articles, e.t.c readily available online, it was much easier for students to read. During the Covid-19 pandemic, many online sites made their sites or e-books freely available or accessible. It was indeed a positive development, which allowed students access to an avalanche of reading resources.

\section{Challenges of Online teaching}

Despite the many advantages of online teaching and learning experienced, it also came with challenges. Here, the lecturers share the challenges they experienced with online education:

Lack of computer and technological skills: The findings of this study indicate that very few lecturers have received formal training in computer skills. Most lecturers reported that they learned computer skills from short training or courses, often ranging from days to weeks. The participants reported that the short computer training or courses they received were sufficient for everyday tasks such as typing, emails, recording grades, etc. However, it did not fully prepare them for the big online teaching task. Online teaching and learning included using web-based communication and virtual learning platforms such as Zoom, Panopto, Moodle, BigBlue Button, Google Drive, Microsoft Teams, WhatsApp, etc. Thus, lecturers need to have fair computer and technological skills to teach and communicate using such platforms. This finding is not unique to the current study as Dube (2020) found similar results where participants also reported a lack of ICT as a hindrance to online teaching.

Loneliness: Loneliness occurs when one is isolated from other people or the community. Many participants mentioned how quiet and alone they felt when face-to-face teaching and learning activities were abruptly halted. The campus went from a busy, hive of activity place to a quiet one. As Alice put it,

Never in my whole teaching career did I think I would miss students. I miss my students. One day I went home crying; the campus was so quiet... it felt like a ghost town. There was no one to annoy me... and I had no one to shout at... (laughing).

Online teaching removes the physical contact and interaction between educators and their students. The participants reported feeling more lonely than usual during this period. The situation was even worse for people who usually work with many people daily, such as lecturers. The sudden move from 
daily interaction with people to staying at home was a change that many were unprepared for. The situation has negatively impacted the mental health of many, with many reporting anxiety and depression during the covid-19 pandemic. Recent studies have reported that during the lockdown, many educators have suffered stress from having to adapt, in a short time, to provide online classes (Besser et al., 2020)

Internet connectivity and availability: One of the challenges mentioned by the participants as having negatively affected online teaching is internet connectivity and availability, especially on the side of students. It was good to note that many lecturers did not experience internet connectivity problems apart from system failure issues. Toini had this to say:

Teaching through the Big Blue Button (BBB) was, at times, frustrating. Sometimes the system was freezing mid-presentation. Interacting with students and changing PowerPoint presentation slides was challenging as the system kept freezing. Due to this, I had to cancel lessons on many occasions.

Although there are many web-based teaching and learning platforms, the University encourages lecturers to teach through $\mathrm{BBB}$, available on Moodle. The high number of users might have led to the system failure experienced by many lecturers and students. Participants indicated that there were times when the Moodle platform was entirely off for the whole day.

Poor attendance: Another challenge experienced by Lecturers during online teaching is the small number of students who logged on for live lessons. Noni described how she would sometimes log in for a class and only have a handful of students present.

It was very discouraging to have few learners show up for class. There are days when only 15 to 20 out of 80 students joined the live class. I have no choice but to proceed with the lesson. At least I could record the lessons so that those who did not attend the class would access them later. Unfortunately, they have to miss the chance for live interactions and ask questions where they needed clarity.

It is not clear why some students missed live classes. Internet availability and connectivity could be one of the reasons given the economic status of many students. Although the University has made efforts to provide internet devices for students, the data may not be sufficient for students to attend all their live classes.

\section{Conclusion}

The covid pandemic has changed the delivery of education worldwide, and we can conclude that we might never entirely go back to the traditional way of teaching and learning. Online teaching has thus become a necessity to ensure that teaching and learning continues. As discussed above, online teaching and learning have both advantages and disadvantages. This study demonstrated that educators perceive online teaching as beneficial and an 
opportunity to enhance their use of technology in teaching despite the challenges that are associated with it. Education systems must thus build on the advantages identified to strengthen online teaching and learning. Providing support for both educators and students and improving technological infrastructure can improve the online teaching experience. There is a need for training for lecturers in online teaching and learning tools to help overcome the challenges they experienced with teaching online. Furthermore, there is a need for psychosocial support for lecturers to help curb feelings of isolation and loneness during the pandemic.

\section{Recommendations for further research}

There are gaps in knowledge about the benefits and challenges of online teaching and learning that follow from the findings of this study and would benefit from further research, and are listed below:

1. Mental health for lecturers and students during the Covid-19 pandemic.

2. Strategies to strengthen online teaching and learning.

3. Benefits and challenges of online teaching from students' perspective. 


\section{References}

Assareh, A. \& Bidokht, M.H. (2010). Barriers to e-teaching and e-learning. Procedia Computer Science. 3(2011), 791-795 DOI:10.1016/j.procs.2010.12.129 Besser, A., Flett, G. L., \& Zeigler-Hill, V. (2020). Adaptability to a sudden transition to online learning during the COVID-19 pandemic: Understanding the challenges for students. Scholarship of Teaching and Learning in Psychology. Advance online publication. https://doi.org/10.1037/st10000198 Bhardwaj A, Nagandla K, Swe KMM, Abas ABL. Academic Staff Perspectives Towards Adoption of ELearning At Melaka Manipal Medical College: Has E-Learning Redefined Our Teaching Model? . Kathmandu Univ Med J 2015; 49(1):12-8. https://doi.org/10.3126/kumj.v13i1.13746 PMID: 26620743

Dube, B. (2020). Rural Online Learning in the Context of COVID-19 in South Africa: Evoking an Inclusive Education Approach. Multidisciplinary Journal of Educational Research, 10(2), 135-157. DOI: 10.4471/remie.2020.5607

Gay, L.R., Mills, G.E. \& P. Airasian, P. (2012). Educational research: Competencies for analysis and applications (10th Ed.). Pearson.

Horner S, Classick R, Warren H, Durbin B. A Study on Teaching and Electronic Assessment Methodologies for the KFIT Project in Rwanda. National Foundation for Educational Research (NFER), UNESCO.2018: 131.

Johnson, B. \& Christensen, L. (2012). Educational research: Quantitative, qualitative and mixed approaches (4th ed.). Sage Publications Inc.

Luchetti, M., Lee, J. H., Aschwanden, D., Sesker, A., Strickhouser, J.E., Terracciano, A. \& Sutin, A. R. (2020). The trajectory of loneliness in response to COVID-19. American Psychological Association, 75(7) 897-908. http://dx.doi.org/10.1037/amp0000690

Mathew, I.R. \& Iloanya, J.E. (2016). Open and distance learning: Benefits and challenges of technology usage for online teaching and learning in Africa. Proceedings of the Pan-Commonwealth Forum 8(PCF8)

Ministry of Education, Arts and Culture (2020). Guideline for the resumption of face-to-face schooling during the post-COVID-19 national lockdown. Windhoek: Namibia.

Moses, M. (2010, May 09). University World News: African Addition. Retrieved from University World News: https://www.universityworldnews.com/post.php?story=20100507211902877 Mukhtar, K., Javed, K., Arooh, M. and Sethi, A. (2020). Advantaged, limitations and recommendations for online learning during CIVID-19 pandemic era. Pak J Med Sci, 36(COVID19-S4), S27-S31, https://dx.doi.org/10.12669\%2Fpjms.36.COVID19-S4.2785

Mutisya, D. N. \& Makokha, G. L. (2016). Challenges affecting adoption of elearning in public universities in Kenya. E-Learning and Digital Media, 13(34) 140-157. https://doi.org/10.1177/2042753016672902 
Oncu S, Cakir H. Research in online learning environments: Priorities and methodologies. Computers \& Education. 2011; 57(1), 1098-1108. https://doi.org/10.1016/j.compedu.2010.12.009

Protsiv, M. \& Atkins, S. (2016). The experiences of lecturers\& for the ARCADE consortium (2016 in African, Asian and European Universities in preparing and delivering blended health research methods courses: a qualitative study, Global Health Action, 9:1, DOI: 10.3402/gha.v9.28149

Sithole, A., Mupinga, D.M., Kibirige, J.S., Manyanga,F. \& Bucklein, B.K. (2019). Expectations, challenges and suggestions for faculty teaching online courses in higher education. International Journal of Online Pedagogy and Course Design, 9(1), DOI: 10.4018/IJOPCD.2019010105

Stone, M. T. \& Perumean-Chaney, S. (2011). The benefits of online teaching for traditional classroom pedagogy: A case study for improving face-to-face instruction. Journal of Online Learning and Teaching, 7(3), 393-400.

World Health Organisation (WHO) (2020). WHO, W. H. (2020, March 11). WHO. Retrieved from WHO: https://www.who.int/directorgeneral/speeches/detail/who-director-general-s-opening-remarks-at-themedia-briefing-on-covid-19---11-march-2020 2006;3(2):77-101.

Zalat, M. M., Hamed, M. S., \& Bolbol, S. A. (2021). The experiences, challenges, and acceptance of e-learning as a tool for teaching during the COVID-19 pandemic among university medical staff. PloS one, 16(3), $\mathrm{e} 0248758$. 


\section{APPENDIX}

\section{Interview guide:}

Purpose of the study

The study aimed to explore the benefits and challenges of online teaching and learning as experienced by lecturers during the COVID-19 pandemic at the Rundu Campus of the University of Namibia.

\section{General information}

I kindly request you to take part in this research on the benefits and challenges you may have experienced with online teaching and learning. There are no right or wrong answers; therefore, be as honest as possible. Furthermore, please take note that responses will be treated with confidentiality and will only be used for purposes of this study. The interview will take about one hour.

Thank you for your willingness $t$ participate in the study

\begin{tabular}{|c|c|}
\hline \multicolumn{2}{|l|}{ Biographical information } \\
\hline $\begin{array}{ll}\text { - } & \text { Age } \\
\text { - } & \text { Sex } \\
\text { - } & \text { Lecturing experience } \\
\text { - } & \text { Training in ICT }\end{array}$ & \\
\hline Research objectives & Interview questions \\
\hline $\begin{array}{l}\text { 1. Investigate the challenges of } \\
\text { online teaching as } \\
\text { experienced by lecturers' } \\
\text { during the COVID-19 at the } \\
\text { University of Namibia }\end{array}$ & $\begin{array}{l}\text { As a Lecturer, what did you find to be } \\
\text { the benefits of online teaching and } \\
\text { learning? } \\
\text { (follow-up questions and probes when } \\
\text { necessary) }\end{array}$ \\
\hline $\begin{array}{l}\text { 2. To describe the benefits of } \\
\text { online teaching as experienced } \\
\text { by lecturers' during the } \\
\text { COVID-19 at the University } \\
\text { of Namibia }\end{array}$ & $\begin{array}{l}\text { As a Lecturer, what challenges did you } \\
\text { experience with online teaching and } \\
\text { learning? } \\
\text { (follow-up questions and probes when } \\
\text { necessary) }\end{array}$ \\
\hline
\end{tabular}

